\title{
Solo-Self-Employment, Human Capital and Hybrid Labour in the Gig Economy
}

\author{
Dieter Bögenhold \\ Professor, Department of Sociology, Dieter.Boegenhold@aau.at \\ Robert Klinglmair \\ Researcher, Department of Economics, Robert.Klinglmair@aau.at \\ Florian Kandutsch \\ Expert, Department of Economics, Florian.Kandutsch@aau.at
}

Alpen-Adria-Universitat Klagenfurt, Universitatsstrasse 65-67, 9020 Klagenfurt am Worthersee, Austria

\begin{abstract}
I
$\mathrm{n}$ the framework of changing contextual factors, this paper deals with one-person enterprises as the smallest units Lof entrepreneurial companies, which already represent more than $50 \%$ of Austrian companies. Within these microenterprises, a special group of self-employed can be identified at the blurred boundaries between dependent work and self-employment: the hybrid solo-self-employed, who are primarily operating as a sideline business. These hybrid forms enormously differ from regular entrepreneurs that
\end{abstract}

Abstract

\section{Keywords:}

structural change; labour market; gig economy; self-employment; entrepreneurship; hybridity; human capital perform their self-employment as their main business. Based on our own empirical survey, the paper aims to examine whether hybrid entrepreneurs are a homogeneous group or if differences exist with respect to their human capital. Our findings reveal several differences concerning for example, (dependent and self-employment) income, working hours, or one's main workplace. it can be summarized that education matters when looking at the different aspects of hybrid selfemployment activity.

Citation: Bögenhold D., Klinglmair R.,

Kandutsch F. (2017) Solo Self-Employment, Human Capital and Hybrid Labour in the Gig Economy. Foresight and STI Governance, vol. 11, no 4, pp. 23-32. DOI: 10.17323/2500-2597.2017.4.23.32 


\section{Introduction: Change as the only Constant}

The philosopher Heraclitus of Ephesus was right. Centuries before the start of our modern Christian computation of time, he claimed that everything is changing and nothing stands still. Speaking of capitalistic societies, Joseph Alois Schumpeter stated that capitalism must be seen as an evolutionary process, which, by its nature, never can be stationary [Schumpeter, 1942]. Societies are in a process of flow. They are constantly changing as time passes due to the 'products' of the society in a given period of time. Nowadays, of course, things are also changing. A technological revolution centered on information and communication technologies has reshaped and is still reshaping the fundamental basis of our society.

So, as time marches on, the institutional settings of societies are in the process of transition altering the foundations of the very same societies. Nowadays, this transition is accelerating from period to period due to major achievements in modern information and communication technologies. As labor markets are closely linked to the characteristics of societies, they are also facing massive structural changes, which affect the composition of the labor markets and, in particular, the self-employed part thereof. One section of the paper will take a closer look at the changing contextual factors with a focus on the implications for the labor market, in particular for the (solo) self-employed. This paper deals with a special group within the sector of self-employment, which is receiving increasing interest from scholars in that field: the hybrid (solo) self-employed. Within this group, we are facing great heterogeneity with respect to different aspects and we can see a rise of blurred boundaries between dependent work and self-employment. The majority of the self-employed are working as a one-man- or one-woman-firm, which raises the need for challenging established views on self-employment and entrepreneurship. Why it is useful to engage in a discussion about the stereotypical views of the self-employed or entrepreneurs will be an important topic with which this paper deals.

The overall aim of this paper is to examine the differences within the special group of solo-self-employed persons belonging to the hybrid category. A special focus in this paper lies on differences with regard to their educational background. Based on our own empirical study, the findings reveal that there are differences with respect to the different educational levels. The empirical part of the paper takes up several of these findings and tries to discuss them within the framework of the great heterogeneity that underlies this group. As a starting point for our discussion, the first part of this paper focuses on the development of self-employment in the 20th century.

\section{Decline, Stabilization and Rise of Self-employment}

The 20th century was the century of the establishment of contractual labor in the modern form, where wage- or salary-dependent work was typical for the great majority of people in the employment system. People are formally free entities who can enter into contracts on the basis of existing rules set down by labor laws, although this freedom was limited through the power of supply and demand on the labor market. If the individual has no alternative other than to accept a specific contract offer, actual freedom is fairly limited because the choices are limited. The establishment of rationality within such a contractual society is portrayed in Max Weber's reflections on the sociology of law [Weber, 1978]. The 'iron cage' [Weber, 2003] is based upon technological efficiency, control, and rational calculation and can also be described, in the words of George Ritzer [Ritzer, 1993], as the McDonaldization of society. Hand in hand with the rise of industrial capitalism and the establishment of the historically new contract system including labor laws, social security, and welfare rights, went the rise of mass production.

In parallel with the rise of mass production, modern societies experienced a general decline of selfemployment within nearly all OECD countries over the course of the 20th century. Much of this decline goes back to the decline of employment in the agricultural sector due to the enormous increases of productivity achieved in the sector. Research on institutional factors [Acs et al., 1992; Staber, Bögenhold, 1993] indicated a variety of components, which influenced the ratios of self-employment. Specifically, the relative ratios of unemployment remain in direct connection with self-employment ratios. Crossnational research for a series of different OECD countries showed that an upsurge in unemployment was always responsible for an upswing in self-employment ratios for a time span of several decades [Bögenhold, Staber, 1991].

The historical decline of self-employment has come to a relative standstill, or self-employment has even been experiencing a slight revival since the 1980s, although different countries show different patterns of concrete development. For a series of selected OECD countries within an observation period of 1955-2015, Figure 1 indicates that the direction of development coincided between most of the countries although the relative levels of departure and change differ.

Looking at self-employment, ratios show a specific level of self-employment within a specific time, but this view hides the fact of inter- and intragenerational social mobility behind the figures. The figure may remain the same, while at the same time multiple inflow and outflow dynamics are taking place. Sociological stratification and mobility research shows the high dynamics between wage dependent work and unemployment on the one hand and self-employment on the other. In other words, self-employment as a category continuously receives fresh blood and loses old blood through 'underground mobility'. Labor market dynamics and social mobility patterns are of great interest to researchers focusing on the division of occupations and related dynamics in the economy [Arum, Müller, 2004].

Empirically divergent paths and the logic of people moving towards self-employment must be taken into account so that not only one typical manner of recruitment is visible, but several different types, each with a competing social logic. In contrast to stereotypical assumptions, the phenomenon of self-employment may look entirely different when it is studied as a phenomenon embedded in labor markets and specific occupational contexts, applications, and sectors. Some types of small businesspeople and independent 
Figure 1. Ratios of Self-Employment in OECD countries from 1955-2015(\%)

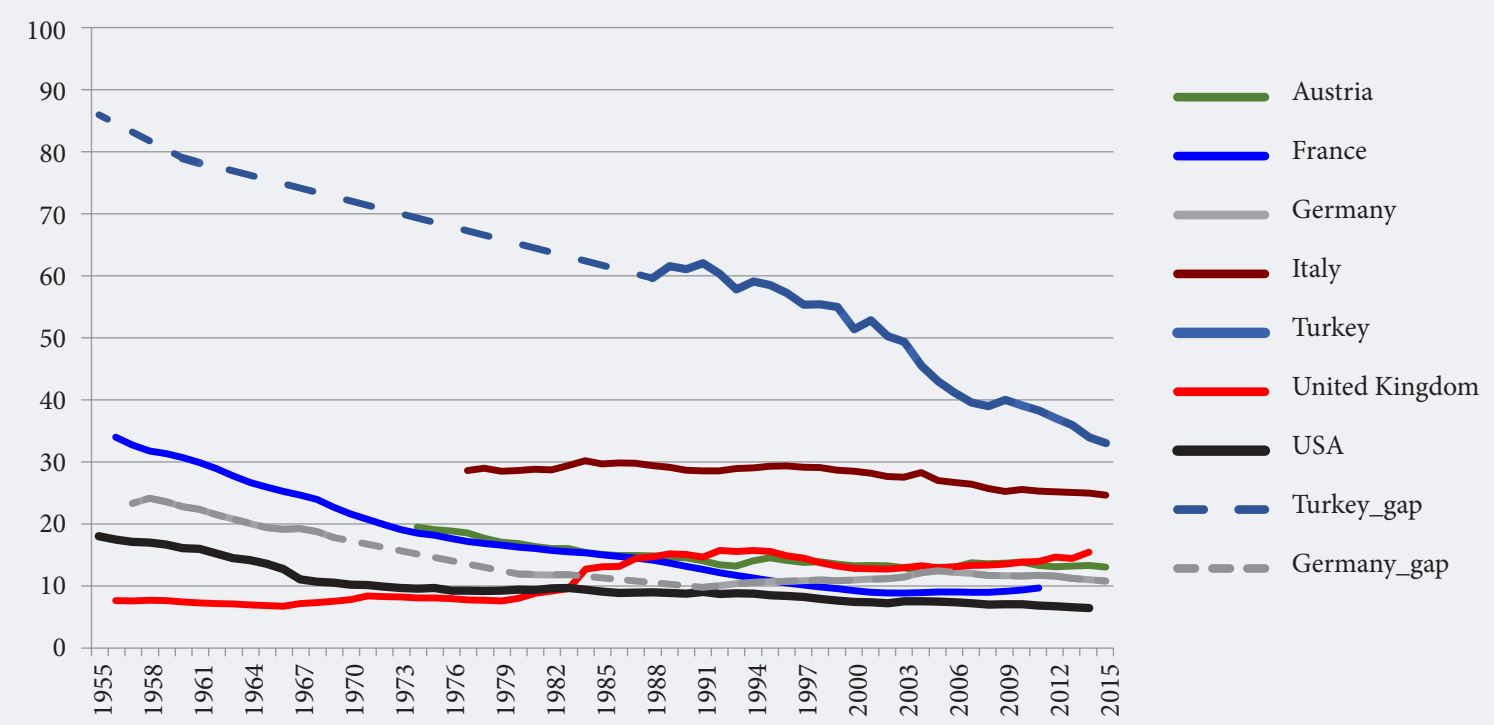

Source: compiled by the authors based on [OECD, 2017].

professionals belong to a category that does not fit with the image of entrepreneurship [Burke, 2011; Burke, Cowling, 2015]. They do not show ambitions for growth and they operate in routines, which are sometimes very close to low income ranges, occasionally to poverty [Shane, Venkataraman, 2000]. Empirical studies on the diverse groups of self-employed individuals in larger societal and labor market contexts may produce alternative pictures, challenging stereotypical assumptions and the types of rhetoric related to self-employment and independent business [Blackburn, Kovalainen, 2008; Kautonen et al., 2010; Bögenhold, Fachinger, 2013; Cieslik, 2015; van Stel, de Vries, 2015].

\section{Digitalization and the Gig Economy: Changing Contextual Factors}

Behind the regular development of the rises and falls in self-employment, one has to acknowledge global trends towards a decline in employment in agriculture and the de-industrialization of economies and societies, which leads to the increasing weight of employment in the tertiary sector. According to OECD data on labor force statistics [OECD, 2015], nowadays between $75 \%$ and $85 \%$ of the total labor force is engaged in work in the tertiary sector, whereas in the middle of the 20 th century only between $30 \%$ and $45 \%$ of the labor force was located there. According to this, the vast majority of people in the employment system is no longer engaged in manufacturing or primary production, but is associated with some kind of post-industrial production [Bell, 1973]. Of course, even the tertiary sector is very widespread and Bell [Bell, 1973, chapter 1] added a quaternary (trade, finance, insurance, real estate) and quinary sector (health, education, research, government, recreation) in order to highlight the different segments of the so-called post-industrial society. In the historical timeframe encompassing the last century, if not centuries, we can see a decisive change of the social landscape of human life. Among other historically significant developments, those of particular interest are centered around innovations regarding information technologies and have constituted a new technological paradigm. These innovations have reshaped and still are reshaping our society and everything that is part of it [Mokyr, 2002; Jin, 2016]. Due to the fact that we are living in a capitalistic society, which is characterized by constant movement [Schumpeter, 1942], we are always facing transitions. However, the remarkable point nowadays is the pace with which this overhauling process of the capitalistic system itself can be observed. One of the earliest and most central insights of economic science was that continuous development involves structural change [McCloskey, 2010]. Besides many other important implications caused by this general overhauling, the changing structure of the labor market is of particular interest [Castells, 2010].

The digitalization of economic activities and the emergence of newly networked enterprise units resulted in the shortening of the time period per operation and the acceleration of the turnover of resources. New management techniques have changed and increased the speed of financial transactions to hours, minutes and seconds due to the availability of new information technologies, with which well-defined software and programs can generate losses or gains by quasi-instantaneous decisions [Jin, 2016]. What truly matters for every social process and form is the actual interaction between the modes of development and the modes of production ('the living flesh of societies') enacted by social actors in often unpredictable ways within a framework of past history and current conditions of technological and economic development surrounded by great uncertainty [Mokyr, 2002; McCloskey, 2010].

The most decisive factor (historically) accelerating, channelling, and shaping the information technology paradigm was the process of capital restructuring, which has been undertaken since the 1980s. This process led, in a nutshell, to a series of reforms (the deregulation, privatization and dismantling of the social contract between labor and capital). Four goals were pursued: (1) deepening the capitalist logic of profit-seeking in 
capital-labor relationships, (2) enhancing the productivity of labor and capital, (3) globalizing production, seizing the opportunity of the most advantageous conditions for production, and (4) marshalling the state's support for productivity gains and the competitiveness of economies. Without the new information technology, the capitalist restructuring would have been much slower, with much less flexibility [Castells, 2010]. When we speak of the 'information society' and the new semantic of a 'gig economy', we have to acknowledge that these societies are capitalist societies and that they always experience some degree of cultural and institutional diversity.

The shift to a tertiary, quaternary, and quinary economy went hand-in-hand with the transformation of the structure of occupations, educational profiles and the division of firms. The fourth logistical revolution brought new competitive factors [Andersson, Andersson, 2017] including new communication networks, cognitive skills, creativity in scientific research and R\&D, complexity of goods/services, and new forms of education, further education, and work training. Deming [Deming, 2015] shows, for the United States, the change of required job skills in the period from 1980 to 2012, when the component of social and mathematical skills had increased in different compositions but did so steadily.

When we discuss the level, quantity, and quality of recent work profiles we must also take into account that new phenomena are appearing due to the new technological opportunities in the gigeconomy, first of all, crowdwork and 'work on demand via apps'. Crowdwork is work that is "executed through online platforms that put in contact an indefinite number of organizations, businesses, and individuals through the internet, potentially allowing for connecting clients and workers on a global basis" ... while 'work-on-demand' via apps refers to "jobs related to traditional working activities such as transport, cleaning, and running errands, but also forms of clerical work, are offered and assigned through mobile apps" [de Stefano, 2015]. Of course, the last group is not homogeneous and the most relevant distinction can be drawn between apps that match demand and supply of different activities such as cleaning, running errands, home-repairs and other apps that offer more specialized service such as driving, or even some forms of clerical work such as legal services or consultancy [de Stefano, 2015, pp. 2-3; Aloisi, 2015].

\section{Solo-Self-Employment as an Independent Case Study}

Contextualizing the object of investigation [Welter, 2011] implies acknowledging that the shift to the service sector in general, and to digitalization in particular, fosters a relative move towards increasingly smaller units of self-employment [Cieslik, 2017]. Especially when talking about the organization of firms, many contemporaries forget that the vast majority of firms consist of small and medium-sized units. Additionally, among these, most belong to the category of the smallest firms, where the owner operates as a one-man or one-woman firm, where the owner is synonymous with the firm and vice versa [Wynn, 2016]. Furthermore, many freelancers are located in this group, where they are statistically not always counted as firms, but belong to the group of self-employed occupations.

As Table 1 indicates, the share of solo-self-employed people is remarkably high with regard to the total amount of self-employed persons. In this table, only a few member states were picked to show the relevance of the solo-self-employed, but it should be stated here that no country within the EU has a share below the $50 \%$ mark, while the average for the European Union is even higher than $70 \%$.

Interpreting new markets as a complex result of occupational changes at the macro level and social mobility within the biographies of individual agents, gives one an idea of how changes serve as sources of newness and innovation. The existence of new and, at least initially, small firms is nurtured above all else by the shift in the economy towards the service sector [Castells, 2010]. First of all, new occupations and job profiles are emerging. These are then in turn associated with the emergence of a multiplicity of new selfemployed occupations and job profiles. The significance of growth in professional services for the future of self-employed activity is revealed by a look at the trend in those occupations, which belong primarily to the segments of business services and education, health and culture. Principle changes in society provide a basic foundation for new areas of independent, liberal professions as well as for new firms in the service

Table 1. The Share of Solo-Self-Employed Persons in Selected EU Member States

\begin{tabular}{|l|c|}
\hline EU country & \% \\
\hline EU average & $\mathbf{7 1 . 4 4}$ \\
\hline Romania & 93.45 \\
\hline United Kingdom & 83.40 \\
\hline Lithuania & 79.33 \\
\hline Czech Republic & 78.95 \\
\hline Netherlands & 75.32 \\
\hline Italy & 71.77 \\
\hline Spain & 70.72 \\
\hline France & 61.38 \\
\hline Austria & 59.88 \\
\hline Germany & 54.75 \\
\hline Source: compiled by the authors based on [Eurostat, 2016a]. & \\
\hline
\end{tabular}


sector, especially when the so-called creative industries [Florida, 2002; Flew, 2012] also became a domain of professional expertise and when trends of globalization and company strategies of outsourcing interact [Oshri et al., 2008; Bharat, 2012].

Due to the increased recent trends and related flexibility and uncertainties, people show up in the cloak of self-employment who are sometimes just de facto laborers without social security benefits [Kalleberg, 2011]. On the other hand, due to general changes in lifestyles and values, an increasing number of freelancers are emerging, who just want to work on their own without being involved in hierarchies [Hytti, 2005], not solely, but often, in the growing IT sector [Shevchuk, Strebkov, 2015]. Independent liberal professions are definitely not regarded as 'core entrepreneurs'. Bögenhold et al. [Bögenhold et al., 2014] have shown that even between the various groups of freelancers in Finland, sometimes huge differences in labor market behavior and attitudes exist (for the context in the UK, see [Burke, 2011; Kitching, Smallbone, 2012]). Some types of small businesspersons and independent professionals belong to a category that does not fit with the traditional image of entrepreneurs as risk-takers and innovators. They do not show ambition for growth and they are sometimes very close to the low income ranges, occasionally even to poverty [Bögenhold, Fachinger, 2016]. Empirical studies on diverse groups of self-employed individuals in larger societal and labor market contexts produce alternative pictures that challenge stereotypical assumptions and rhetoric related to entrepreneurship. They highlight the heterogeneity of the occupational category of self-employment.

Findings reveal that the life and work situation of self-employed and liberal professions cannot be interpreted in simple black and white schemes, such as 'close to poverty' and pushed by missing employment opportunities into the sector of work for wages on the one hand versus working without hierarchies and being independent and self-realized on the other. Instead, many different socioeconomic situations can be found 'in between', which are driven by differing social approaches. However, looking at the margins of the economy contributes to challenging some stereotypes about self-employment or entrepreneurship [Friedman, 2014]. McKeown [McKeown, 2016] has shown that the actors are often not entirely certain about their own classification. Their self-definition oscillates between entrepreneur, self-employed person, consultant, independent professional (I-pro), or simply contractor. It is not always clear, if we have to speak about a professional contractor or an independent professional [Johal, Anastasi, 2015]. Self-employment is very often a biographical period and takes the form of being a social process within the course of one's lifetime [Mayer, 2009; Kohli, 2007].

Being part of a so-called entrepreneurial society [Audretsch, 2007] must be furnished sociologically: in doing so, we also have to acknowledge a variety of 'non-standard' forms of self-employment, including part-time self-employment, self-employment just for brief periods, freelancers, and other different sectoral activities (such as, e.g., farmers).

Full-time working freelancers, farmers, micro-entrepreneurs without employees, and 'big' entrepreneurs employing a larger share of wage- or salary-dependent employees are difficult to summarize in one single box. The black and white dichotomy of being dependent or self-employed seems to neglect the multiplicity of inflow and outflow processes, which take place constantly behind the aggregate figure and which are very often related to complex processes of individual attempts to increase one's social status. Therefore, those new forms of self-employment are difficult to define, since parts are pushed out of necessity while others are pulled and a sign of choice; parts belong to the new gig economy, while others work in relatively traditional sectors [McKinsey, 2016]. Last, but not least, we are experiencing the phenomenon that people fall into more than one box, they are self-employed and wage- or salary-dependent employees simultaneously.

When dependent workers and independent actors sometimes have overlapping identities, we may call them hybrid entrepreneurs [Folta, 2007; Folta et al., 2010; Raffiee, Feng, 2014; Schulz et al., 2016]. While 'die-hard entrepreneurs' [Burke et al., 2008] are those actors, who are primarily portrayed in public discourse and in economic literature, namely those actors who are dynamic, willing to expand and to take risks, hybrid (self-employed) laborers seem to be of a different nature. This empirical study will further discuss those hybrid forms of self-employment. Specifically, following our own previous empirical findings, we will explore whether or not qualification matters when dealing with positive or negative aspects of hybrid selfemployment.

\section{Empirical Findings on Hybrid Self-Employment: Does Human Capital Matter?}

In Austria, the category of solo-entrepreneurs accounts for $59.9 \%$ of all self-employed according to the Eurostat Database [Eurostat, 2016a, b]. The share of solo-entrepreneurs within total self-employment in the EU-28, by contrast, accounts for $71.5 \%$. Even though Austria is below the EU-28 average, we can see the importance of micro enterprises without employees, which account for far more than the half of all selfemployed people. Moreover, Austrian statistics indicates the significant relevance of enterprises led by one man or woman. The Austrian public census of company units shows that 322,889 firms are led by a solo entrepreneur, representing 61.8\% of all firms located in Austria [Statistik Austria, 2015]. A lower level of solo-self-employed is presented by the Austrian Chamber of Commerce ('Wirtschaftskammer Österreich'; WKO). This is caused by the exclusion of a variety of types of freelancers, who do not have to be registered at the chamber. WKO data show the share of one-person-enterprises, compared with the total number of enterprises registered, which amounts to 58.9\%. In absolute figures, the WKO counts 290,061 units of solo-self-employed persons in the whole of Austria. Compared with the previous year, the figure of soloself-employed people has risen by $4.2 \%$. If we look at the federal state of Carinthia, which is of interest in our empirical section, 18,097 one-person-enterprises are listed in the register of the Austrian Chamber of Commerce. The share of microenterprises without further employees amounts to 57.3\% for Carinthia, which is slightly below the Austrian average. More than $60 \%$ of all solo firms have their domains in the business and creative sectors, as well as in the information and consulting sectors. Also, the trade sector, with a share of $48.5 \%$, has a high number of solo firms [Wirtschaftskammer Österreich, 2015]. 
After the evaluation of data from official European and Austrian statistics, we can see that one-personenterprises play a very important role in the European and Austrian business sector, since they make up the majority of enterprises. However, there is a lack of information about the group of hybrid-entrepreneurs. The group of hybrids are those firms where the owner is involved in more than one activity. The question we raise is how the education of those hybrid-entrepreneurs accounts for the emerging differences. Are there serious differences within this group, if we look at the educational background and if yes, where do they emerge? In order to answer the questions, a broad online survey was implemented in cooperation with the Carinthian Chamber of Commerce. The survey is based on a questionnaire containing 52 questions in total. The questionnaire was developed and tested in a long process lasting several months. It was finally adapted with the help of LimeSurvey. The questionnaire contains questions about the motives behind selfemployment, client relations, success and satisfaction with self-employment, future prospects of the soloself-employed, and socioeconomic characteristics.

A total of 9,002 one-person enterprises were contacted by the Carinthian Chamber of Commerce in February 2014 and invited to participate in an online survey. The response rate of $7.0 \%$ resulted in a sample size of 626 one-person-enterprises, which is representative with respect to the legal form (over $90 \%$ of the sample comprised individual entrepreneurs), age (mean age in the sample and in the total population: 47 years), and gender, with males being slightly overrepresented in the sample compared with the total population. Several findings of the study are published in more detail elsewhere [Bögenhold, Klinglmair, 2014, 2015a, 2015b, 2016a, 2016b, 2016c; Klinglmair, Bögenhold, 2014].

The complex interaction between technological development, globalization and socio-demographic change has accelerated the structural change of the economy resulting in a changing working environment and new forms of employment. Concerning the field of self-employment, in many countries an emerging trend can be observed towards one-person enterprises, which, for example, already represent more than $50 \%$ of all Austrian companies as described above. One clearly has to keep in mind that these microenterprises are by far not homogeneous in a variety of aspects like motives for self-employment [Bögenhold, Klinglmair, 2015a, 2015b] or by gender on the one hand, and by the extent of additional economic activities [Bögenhold, Klinglmair, 2016a, 2016b, 2016c] on the other. For instance, we found evidence that one-person entrepreneurs are mainly driven by motives such as self-realization or working without hierarchies [Bögenhold, Klinglmair, 2015a]. However, there is also a large group of self-employed (25.2\%) that has been crowded out of the (dependent) labor market. These one-person entrepreneurs decided to start their business due to labor market reasons and are therefore driven by economic reasons; thus, self-employment primarily represents an alternative to unemployment. Moreover, this economically driven group of one-person enterprises is relatively dissatisfied with their professional situation, is less optimistic regarding their entrepreneurial future, and generates lower incomes [Bögenhold, Klinglmair, 2015a, p. 107]. Blurred boundaries between dependent work and self-employment exist. These boundaries are fluid and dynamic in their nature and do not fit with the idea of a clean division that separates the sphere of dependent work neatly from that of independent work. These overlapping phenomena, when people combine both categories and dependent workers as well as independent actors, have overlapping identities [Bögenhold, Klinglmair, 2016a, 2016b, 2016c] and are very often neglected in the research and are addressed in this paper.

In the collected (and described) data sample, beside 398 one-person enterprises (63.6\%) that are solely selfemployed and perform no additional activities, another $18.5 \%$ (or 116 one-person enterprises) that have an additional dependent employment beside their business have been identified; this group can be described as 'hybrid' entrepreneurs. We investigated whether this additional dependent employment represents a necessity-driven secondary job to survive economically, or whether the one-person enterprise, namely the self-employment activity, represents only a secondary source of income [Bögenhold, Klinglmair, 2016a]. Based on five indicators (e.g., monthly net income from dependent employment; for details see [Bögenhold, Klinglmair, 2016a, p. 133]) we identified that more than half of the hybrid one-person enterprises (53.3\%) only operate as a sideline business; self-employment activity indeed represents only a secondary source of income [Bögenhold, Klinglmair, 2016a, p. 136]. Moreover, hybrid self-employment significantly differs from non-hybrid 'regular' entrepreneurs with respect to socio-demographic characteristics as well as professional and company-specific factors [Bögenhold, Klinglmair, 2016c]. For example, the group of regular entrepreneurs primarily works at their own office compared to hybrid forms of entrepreneurship, which are operated as a sideline business mainly at home. In addition, hybrid entrepreneurs significantly focus more often on regional customers and markets. Furthermore, hybrid entrepreneurs are significantly younger (43.6 vs. 48.0 years on average), their businesses exist for shorter periods of time than regular oneperson enterprises (6.9 vs. 9.5 years on average) and they have lower annual turnover, and, respectively, a lower monthly income from self-employment due to the fact that they spend less working time on their business and conversely earn more from the (primarily full-time) dependent employment; for more details see [Bögenhold, Klinglmair, 2016c, pp. 8-10]).

Using a logistic regression model, we additionally investigated several factors that determine the probability of the occurrence of hybrid entrepreneurship [Bögenhold, Klinglmair, 2016b]. Beside age, the situation in which the one-person enterprise was founded, the duration of the enterprise, as well as the motives for being self-employed, two important determinants were identified. First, the family background does not play a significant role for explaining hybrid self-employment. The presence of a working partner did not turn out to be a statistically significant influencing factor. This result may be caused by the fact that the additional dependent employment is in most cases not necessity-driven [Bögenhold, Klinglmair, 2016b, p. 15]. Second, one-person enterprises where the person has a tertiary education are more likely to be additionally (dependently) employed compared to their less educated counterparts. This result may also be motivated by the preferable situation of academics on the (regular) labor market. In figures, one-person enterprises with a tertiary education are, all else being equal, about twice as likely to be employed alongside their business activities than less educated hybrid entrepreneurs [Bögenhold, Klinglmair, 2016b, p. 16]. 
Figure 2. Monthly Net Income from Additional Dependent Employment (\%)

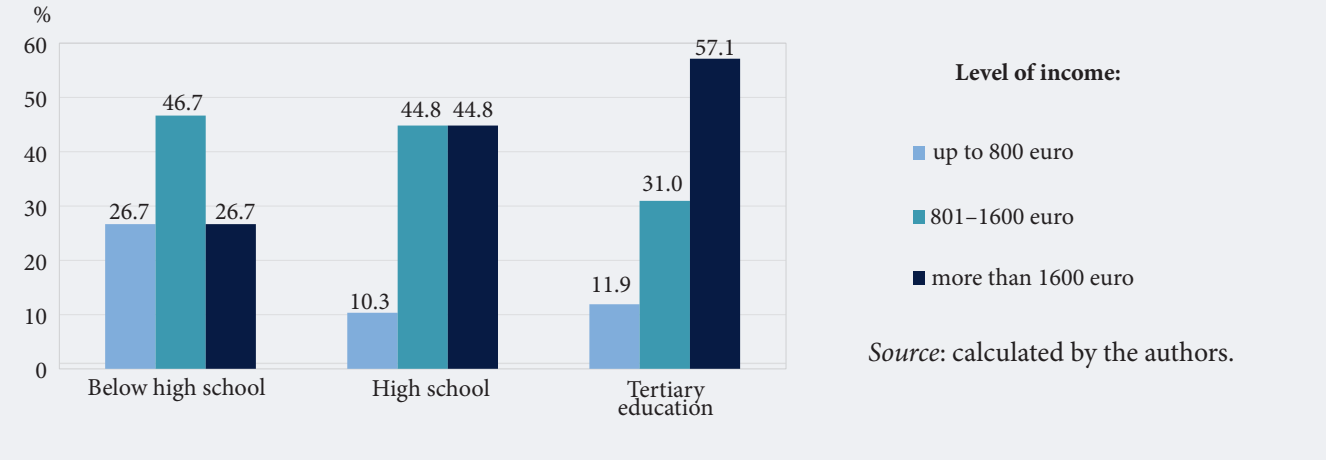

This can, on the other hand, also be reflected by the fact that hybrid one-person enterprises are significantly better educated in the collected data sample, as more than one-third (36.2\%, 42 persons) has completed a tertiary education, while this applies to only $24.7 \%$ (126 persons) of the non-hybrid entrepreneurs. Conversely, the share of solo-entrepreneurs with an educational level below high school is significantly lower within the group of the hybrid self-employed (38.8\% or 45 persons vs. $49.6 \%$ or 253 persons). ${ }^{1}$ In summary, we can conclude the following: (1) a large share of one-person enterprises in Carinthia are forms of hybrid entrepreneurs that operate their business as sideline business and (2) these hybrid forms differ enormously from regular entrepreneurs that represent their self-employment as their main business. What remains open is whether hybrid entrepreneurs can be treated as a homogenous group or if they also differ by selected characteristics, where we especially focus on the educational level in the sense of 'whether human capital matters. Are there differences in the amount of the self-employed and/or dependent sources of incomes by educational level and do more highly educated groups achieve higher individual returns on education? What about satisfaction with one's professional career? Can the hybrid solo-self-employed be divided into two groups, namely opportunity-driven and necessity-driven entrepreneurs based on their human capital? These and more questions will be addressed in the following empirical analysis of our data sample.

With respect to the monthly net income from additional dependent employment it can be shown that more highly educated hybrid entrepreneurs (tertiary education level) receive 'returns on education' on the dependent labor market as expected by the human capital theory: the higher the educational level, the higher the dependent income (see Figure 2); this effect is statistically significant based on a contingency table analysis (Pearson- $\chi 2=10.15 ; p=0.038){ }^{2}$ In detail, a share of $57.1 \%$ of hybrid entrepreneurs with tertiary education has a monthly net income above $€ 1,600$; in contrast, only about one-eighth (11.9\%) realizes a dependent net income below $€ 800$. For solo-self-employed persons with educational levels below high school the opposite results can be obtained: a share of only $26.7 \%$ ranges in the highest income category, while more than one fourth earns less than $€ 800$ per month; the majority (46.7\%) earns between $€ 800$ and $€ 1,600$ a month. A similar relationship is observed for medium qualified solo-self-employed (with a high school degree): a share of only $10.3 \%$ earns a monthly net income below $€ 800$; the remaining $89.7 \%$ are allocated equally in the two higher income categories.

Before the analysis is expanded additionally to the relationship between monthly net-income from selfemployment and the acquired human capital, two facts concerning the general low income levels of the hybrid solo-self-employed compared to non-hybrid entrepreneurs (€608 monthly net income on average vs. $€ 1,347$ for non-hybrid entrepreneurs) should be considered. First, hybrid entrepreneurs mainly operate their business as a sideline business, as already described by [Bögenhold, Klinglmair, 2016a, p. 136]); self-employment activity therefore often only represents an additional source of income. Second, the professional fields in which the respondents operate their business generally do not represent the vocational background of the particular entrepreneur as the Kruskal-Wallis Test, an extension of the Mann-Whitney-U Test for more than two groups, shows $(\chi 2(2)=8.89 ; p=0.012)$. Learned skills based on the formal educational background and/or professional experience, respectively, tenure for dependent employment cannot be individually assigned to self-employment activities.

Moreover, a similar effect between self-employment salaries and the educational level, as has been identified for dependent income, cannot be directly observed. For this purpose, the monthly net income was aggregated into two categories; income category 1 with salaries below $€ 1,000$ per month and category 2 with income levels above $€ 1,000$. While hybrid entrepreneurs with a high school degree are located between the two categories as expected, it can be shown that more qualified hybrid entrepreneurs (tertiary education) are slightly overrepresented in category 2 compared to those solo-self-employed without a secondary education. However, these differences are too small and statistically insignificant. The income from selfemployment is therefore independent from the educational level in the collected data sample based on

\footnotetext{
The share of persons with a high school degree amounts to $25.0 \%$ (29 persons) among hybrid entrepre-neurs and $25.7 \%$ (131 persons) for non-hybrid self-employed, respectively.

This result is independent from weekly working hours based on a contingency table analysis; there are no statistically significant differences in working hours by educational level (Pearson- $\chi 2=6.83 ; \mathrm{p}=0.337)$, higher income levels do not therefore result from higher weekly working hours.
} 
a contingency table analysis (Pearson- $\chi 2=3.46 ; p=0.177$ ). Nevertheless, what immediately stands out is that although no significant education-dependent differences in salaries can be identified weekly working hours differ by educational background on a $10 \%$-significance-level (Pearson- $\chi 2=20.83$; $p=0.053$ ). While entrepreneurs with tertiary education are overrepresented in the categories with low(er) working hours (less than 30 hours/weekly), this group is underrepresented in the category with more than 60 hours per week. These findings contradict those for hybrid entrepreneurs with an education level below high school; for instance, this group is overrepresented in the category with 60 hours and above. Hence, if we consider selfemployment income per hour (instead of monthly salary) the relationship between income and educational achievement can be at least observed indirectly for self-employment sources of income as well.

Furthermore, concerning the distribution between industrial sectors of one-person enterprises it was found that differences with respect to sectors between hybrid and non-hybrid solo-self-employed are not statistically significant [Bögenhold, Klinglmair, 2016c, p. 851]. Conversely, if we consider only hybrid soloself-employed and differentiate the business sectors where the hybrid entrepreneurs operate by educational status, significant results based on a contingency table analysis arise. Solo-self-employed with a tertiary education (as well as the group of hybrids with a high school degree) operate in a significantly higher number in prosperous branches such as the manufacturing sector or the information and communications (ICT) branch, while the opposite is true for persons with educational levels below high school. The group of the lowest qualified solo-self-employed perform their businesses to a comparatively higher extent in the trade or tourism sectors and are, conversely, underrepresented in the manufacturing and ICT sectors (Pearson $-\chi 2=26.06 ; p=0.011)$.

Focusing further on the regional distribution of enterprises the data show that medium and high qualified solo-self-employed operate their business primarily in the Carinthian central area (Klagenfurt-Villach), while entrepreneurs without a high school education do their business to a higher extent in Carinthia's rural regions; these differences are significant at a $10 \%$-significance level based on a contingency table analysis (Pearson- $\chi 2=28.21 ; p=0.059)$. Additionally, significant differences concerning the main workplace - again at a $10 \%$-significance-level - arise by qualification status (Pearson- $\chi 2=13.99 ; p=0.082$ ). While, for example, $82.2 \%$ of solo-self-employed firms without a high school degree operate their businesses at home ('home office') or directly at the customers' premises, this is true for a comparatively lower share, $69.0 \%$, of hybrid entrepreneurs with a tertiary education. In contrast, the lowest qualified group is underrepresented in the category 'one's own office' or 'co-working spaces (13.3\% with a lower education vs. $23.8 \%$ of the highly qualified solo-self-employed). For the lowest qualified solo-firms with significantly lower dependent income levels and lower entrepreneurial salaries, operating one's own office or co-working space seems to be unprofitable. Combined with the fact that this group performs their business in rural regions, long(er) distances directly to the customers and thus (transport) costs rise for this already disadvantaged group. Nonetheless, the identified lower (dependent as well as self-employed) incomes and the higher amount of weekly working hours for the more lowly qualified compared to medium and highly qualified solo-selfemployed entrepreneurs have no significant influence on job satisfaction or the satisfaction with one's 'work-life balance' based on two separate Kruskal-Wallis Tests $(\chi 2(2)=0.15 ; p=0.928$ for job satisfaction and $\chi 2(2)=1.02 ; p=0.600$ for satisfaction with one's work-life balance).

With respect to the empirical findings above, it can be concluded that there are two major groups within the examined hybrid solo-self-employed. On the one hand, we have those (highly qualified) actors who pursue an additional job because they see an opportunity to maximize their income, on the other hand there are actors who have to pursue an additional job to compensate for the lower income they receive from their dependent employment arrangement ('necessity-driven'). In other words, we can summarize that we find opportunity-driven entrepreneurs as well as necessity-driven entrepreneurs within the specific group of hybrid solo firms. Although the hybrid solo-self-employed belong to either the first or the latter category, no difference with respect to their job satisfaction can be found. This reflects that fact that necessity-driven entrepreneurs know, at the end of the day, that they have to engage in an additional profession beside their low paid dependent employment to make ends meet, but they accept these circumstances. Similar studies (and results) on the educational background differentiating between opportunity-driven and necessitydriven self-employment have already been conducted (e.g., [Baptista et al., 2013]), but there is much room for further research, in particular with a focus on the hybrid solo-self-employed.

\section{Conclusions and Outlook}

As the 'rules of the game' [Baumol, 1990] change, we have to pay attention to the changing character of selfemployment. Different countries have different specific institutional settings, making it almost impossible to generalize self-employment. Contextual views are necessary to grasp the diversity in self-employment, therefore an acknowledgement of the historical, temporal, institutional, and social contexts is unavoidable [Welter, 2011]. The implication is that we have to respect the different forms of self-employment when talking abstractly about the category of self-employment on the labor market, too diverse are the social, economic and cultural conditions and related biographies. Among the heterogeneity of actors under the umbrella of self-employment the empirical focus of this paper concentrated on the one-(wo)man firms, which are, in other words, self-employed people without further employees. Here, more specifically, we asked about those solo-self-employed who have further sources of income as dependent laborers. This group is most commonly called hybrid self-employment.

Hybrid self-employed actors are difficult to locate exactly between the boundaries of the employee and the self-employed. The two forms of hybrid self-employed are classified as: (1) self-employed having an additional dependent employment relationship to maximize their income and vice versa (2) people having a dependent employment relationship who pursue a form of self-employment to ensure additional income [Bögenhold, Klinglmair, 2016c]. 
Our findings suggest that analyzing the categories of hybrid entrepreneurs shows strong differences according to their human capital. The higher the amount of human capital the higher is, on average, their income, especially income as employees. On the other hand, the lower the level of human capital, the more likely economic actors are just working part-time. Comparing the income of people with low and high human capital through self-employment shows first hand that there are no clear differences regarding education, but those with better education work shorter hours, thus they can realize a greater return on human capital. Neither segments differ regarding work satisfaction and intentions to grow.

We have to rethink the oft used dichotomous perspective when we look at self-employment. 'Black' and 'white' considerations are not sufficient to capture the richness of the actors under the self-employed banner and their specific forms of 'happiness' [Meager, 2015]. In a discussion full of synonyms, some of the affected persons do not even know to which category they belong [McKeown, 2015]. Probably one of the most promising tasks in research is the need to deliver generalizable theoretical contributions that differ from those established or are even in conflict with them [Di Gregorio, 2004]. The great heterogeneity and the very modest amount of 'classic' self-employed persons constitute a difficult challenge for research [Davidsson et al., 2010].

\section{References}

Acs Z., Audretsch D., Evans D. (1992) The Determinants of Variations in Self-Employment Rates Across Countries and Over Time (Discussion paper FS IV 92-3), Berlin: Wissenschaftszentrum Berlin für Sozialforschung.

Aloisi A. (2015) The Rising of On-Demand Work: A Case Study Research on a Set of Online Platforms and Apps. Paper presented at the IV Regulating for Decent Work Conference, ILO, Geneva, 8-10 July 2015.

Andersson D.E., Andersson Å.E. (2017) Time, Space, and Capital, Cheltenham: Edward Elgar.

Arum R., Müller W. (eds.) (2004) The Return of Self-Employment, Princeton: Princeton University Press.

Audretsch D. (2007) The entrepreneurial society, Oxford: Oxford University Press.

Baptista R., Karaöz M., Medoncs J. (2013) The impact of human capital on the early success of necessity versus opportunity-based entrepreneurs. Small Business Economics, vol. 42, no 4, pp. 831-847.

Baumol W.J. (1990) Entrepreneurship: Productive, Unproductive and Destructive. Journal of Political Economy, vol. 98, no 5, pp. 893-921.

Bell D. (1973) The Coming of Post-Industrial Society. A Venture in Social Forecasting, New York: Basic Books.

Bharat V. (2012) Strategic Outsourcing. The Alchemy to Business Transformation in a Globally Converged World, Heidelberg; New York; Dordrecht; London: Springer.

Blackburn R., Kovalainen A. (2008) Researching small firms and entrepreneurship: Past, present and future. International Journal of Management Review, vol. 11, no 2, pp. 127-148.

Bögenhold D., Fachinger U. (2013) Blurred Boundaries of Journalism: Multiple Employment in the Media Industry and the Hybridity of Occupational Work. International Journal of Arts and Commerce, vol. 2, no 10, pp. 171-183.

Bögenhold D., Fachinger U. (2016) Selbständige Erwerbsarbeit: Betrachtungen aus verschiedenen Perspektiven, Wiesbaden: VS Verlag.

Bögenhold D., Heinonen J., Akola E. (2014) Entrepreneurship and independent professionals: Social and economic logics. International Advances in Economic Research, vol. 20, no 3, pp. 295-310.

Bögenhold D., Klinglmair A. (2014) Motive für die Tätigkeit als Ein-Personen-Unternehmen in Kärnten - Ergebnisse einer empirischen Untersuchung. Wirtschaftspolitische Blätter - Sonderaus-gabe, S/14, pp. 137-158. Available at: http://bit.ly/2wtWMwG, accessed 15.06.2017.

Bögenhold D., Klinglmair A. (2015a) Micro-Entrepreneurship: Tendency towards Precarious Work? Empirical Findings for Austria. Athens Journal of Business and Economics, vol. 1, no 2, pp. 107-122.

Bögenhold D., Klinglmair A. (2015b) Female solo-self-employment. Features of gendered entrepreneurship. International Review of Entrepreneurship, vol. 13, no 1, pp. 47-58.

Bögenhold D., Klinglmair A. (2016a) Entrepreneurship and Hybrid Self-employment. Contemporary Entrepreneurship - Multidisciplinary Perspectives on Innovation and Growth (eds. D. Bögenhold, J. Bonnet, M. Dejardin, Pérez de Lema D.G.), Heidelberg; New York; Dordrecht; London: Springer, pp. 127-140.

Bögenhold D., Klinglmair A. (2016b) One-person enterprises and the phenomenon of hybrid self-employment: Evidence from an empirical study. Empirica, vol. 44, no 2, pp. 383-404.

Bögenhold D., Klinglmair A. (2016c) Independent work, modern organizations and entrepreneurial labor: Diversity and hybridity of freelancers and self-employment. Journal of Management \& Organization, vol. 22, no 6, pp. 843-858.

Bögenhold D., Staber U. (1991) The Decline and Rise of Self-Employment. Work, Employment and Society, vol. 5, no 2, pp. 223-239.

Burke A., Fitzroy F., Nolan M. (2008) What makes a Die-Hard Entrepreneur? Trying, or Persisting in Self-employment. Small Business Economics, vol. 31, pp. 93-115. DOI 10.1007/s11187-007-9086-6.

Burke A. (2011) The Role of Freelancers in the 21st century British Economy, London: PCG.

Burke A., Cowling M. (2015) The Use and Value of Freelancers: The Perspective of Managers. The Use and Value of Freelancers: The Perspective of Managers (ed. A. Burke), Dublin: Senate Hall Publishing, pp. 1-14.

Castells M. (2010) The Information Age. Economy, Society, and Culture, vol. I: The Rise of the Network Society, Oxford: Wiley-Blackwell.

Cieslik J. (2015) Capturing Statistically the "Intermediate Zone" Between the Employee and Employer Firm Owner. The Use and Value of Freelancers: The Perspective of Managers (ed. A. Burke), Dublin: Senate Hall Publishing, pp. 29-38.

Cieslik J. (2017) Entrepreneurship in Emerging Economies. Enhancing its Contribution to Socio-Economic Development, Heidelberg; New York; Dordrecht; London: Springer.

Davidsson P., Achtenhagen L., Naldi L. (2010) Small firm growth. Foundations and Trends in Entrepreneurship, vol. 6, no 2, pp. 69-166.

de Stefano V. (2015) The rise of the "just-in-time workforce": On-demand work, crowdwork and labour protection in the "gig-economy", Geneva: International Labour Office.

Deming D.J. (2015) The Growing Importance of Social Skills in the Labor Market (NBER Working Paper 21473), Cambridge, MA: National Bureau of Economic Research. 
Di Gregorio D. (2004) Re-Thinking country risk: Insights from entrepreneurship theory. International Business Review, vol. 14, no 2, pp. 209-226.

Eurostat (2016a) Selbständigkeit nach Geschlecht, Alter und Beruf (lfsa_esgais). Available at: http://ec.europa.eu/ eurostat/data/database, accessed 21.12.2016.

Eurostat (2016b) Beschäftigung nach Geschlecht, Alter und Stellung im Beruf (lfsa_esgais). Available at: http:// ec.europa.eu/eurostat/data/database, accessed 21.12.2016.

Flew T. (2012) The Creative Industries. Culture and Policy, London: Routledge.

Florida R.L. (2002) The rise of the creative class. And how it's transforming work, leisure, community and everyday life, New York: Basic Books.

Folta T.B. (2007) Uncertainty rules the day. Strategic Entrepreneurship Journal, vol. 1, pp. 97-99.

Folta T.B., Delmar F., Wennberg K. (2010) Hybrid entrepreneurship. Management Science, vol. 56, pp. 253-269.

Friedman G. (2014) Workers without employers: Shadow corporations and the rise of the gig economy. Review of Keynesian Economics, vol. 2, no 2, pp. 171-188.

Hytti U. (2005) New meanings for entrepreneurs: From risk-taking heroes to safe-seeking professionals. Journal of Organizational Change Management, vol. 18, no 6, pp. 594-611.

Jin D. (2016) The Great Knowledge Transcendence. The Rise of Western Science and Technology Reframed, New York: Palgrave Macmillan.

Johal S., Anastasi G. (2015) From professional contractor to independent professional: The evolution of freelancing in the UK. Small Enterprise Research, vol. 22, no 2-3, pp. 159-172.

Kalleberg A.L. (2011) Good Jobs, Bad Jobs: The Rise of Polarized and Precarious Employment Systems in the United States, New York: Russell Sage Foundation.

Kautonen T., Down S., Welter F., Vainio P., Palmroos J. (2010) Involuntary self-employment as a public policy issue: A cross-country European view. International Journal of Entrepreneurial Behaviour and Research, vol. 16, no 1-2, pp. 112-129.

Kitching J., Smallbone D. (2012) Are freelancers a neglected form of small business? Journal of Small Business Enterprise Development, vol. 9, no 1, pp. 74-91.

Klinglmair A., Bögenhold D. (2014) Berufliche Zufriedenheit von Ein-Personen-Unternehmen in Kärnten Ergebnisse einer empirischen Untersuchung. Kärntner Jahrbuch für Politik 2014 (eds. K. Anderwald, P. Filzmaier, K. Hren), Klagenfurt: Hermagoras, pp. 197-218.

Kohli M. (2007) The institutionalization of the life course: Looking back to looking ahead. Resources of Human Development, vol. 4, pp. 253-571.

Mayer K.U. (2009) New directions in life course research. Annual Review of Sociology, vol. 35, pp. 413-433.

McCloskey D. (2010) The Bourgeois Dignity. Why Economics Can't Explain the Modern World, Chicago: Chicago University Press.

McKeown T. (2015) What's in a Name? The Value of "Entrepreneurs" Compared to "Self-Employed" ... But What about "Freelancing" or "IPro". The Handbook of Research on Freelancing and Self-Employment (ed. A. Burke), Dublin: Senate Hall Publishing, pp. 121-135.

McKeown T. (2016) A consilience framework: Revealing hidden features of the independent contractor. Journal of Management and Organization, vol. 22, no 6, pp. 779-796.

McKinsey Global Institute (2016) Independent Work: Choice, Necessity, and the Gig Economy, San Francisco: McKinsey Global Institute.

Meager N. (2015) Job quality and self-employment: Is it (still) better to work for yourself? The Handbook of Research on Freelancing and Self-Employment (ed. A. Burke), Dublin: Senate Hall Publishing, pp. 35-46.

Mokyr J. (2002) The Gifts of Athena. Historical Origins of the Knowledge Economy, Princeton: Princeton University Press.

OECD (2015) OECD Labour Force Statistics 2014, Paris: OECD.

OECD (2017) Self-employment rate. Available at: https://data.oecd.org/emp/self-employmentrate.htm, accessed 21.01.2016.

Oshri I., Kotlarsky J., Willcocks L. (2008) Outsourcing global services: Knowledge, innovation and social capital, Basingstoke: Palgrave Macmillan.

Raffiee J., Feng J. (2014) Should I quit my Job? A hybrid path to entrepreneurship. Academy of Management Journal, vol. 57 , no 4 , pp. $936-963$

Ritzer G. (1993) The McDonaldization of society: An investigation into the changing character of contemporary social life, Thousand Oaks: Pine Forge Press.

Schulz M., Urbig D., Procher V. (2016) Hybrid entrepreneurship and public policy: The case of firm entry deregulation. Journal of Business Venturing, vol. 31, no 3, pp. 272-286.

Schumpeter A. (1942) Capitalism, Socialism and Democracy, New York: Harper \& Row.

Shane S., Venkataraman S. (2000) The Promise of Entrepreneurship as a Field of Research. Academy of Management Review, vol. 25, pp. 217-226.

Shevchuk A., Strebkov D. (2015) The rise of freelance contracting on the Russian-language internet. Small Enterprise Research, vol. 22, no 2-3, pp. 146-158.

Staber U., Bögenhold D. (1993) Self-Employment: A Study of Seventeen OECD Countries. Industrial Relations Journal, vol. 25, no 2, pp. 128-139.

Statistik Austria (2015) Arbeitsmarktstatistiken - Ergebnisse der Mikrozensus Arbeitskräfteerhebung und der OffenenStellen-Erhebung, Vienna: Verlag Österreich.

van Stel A., de Vries N. (2015) The Economic Value of Different Types of Solo Self-Employment: A Review. The Use and Value of Freelancers: The Perspective of Managers (ed. A. Burke), Dublin: Senate Hall Publishing, pp. 77-84.

Weber M. (2003) The Protestant Ethic and the Spirit of Capitalism, New York: Dover Publications.

Weber M. (1978) Economy and Society: An Outline of Interpretive Sociology, Berkeley: University of California Press.

Welter F. (2011) Contextualizing entrepreneurship - conceptual challenges and ways forward. Entrepreneurship Theory and Practice, vol. 35, no 1, pp. 164-184.

Wirtschaftskammer Österreich (2015) Ein-Personen-Unternehmen (EPU) 2015. EPU-Anteil nach Sparten (Mehrfachmitgliedschaften) (EinzelunternehmerInnen, $G m b H$ ), Vienna: Wirtschaftskammer Österreich.

Wynn M. (2016) Chameleons at large: Entrepreneurs, employees and firms - the changing context of employment relationships. Journal of Management and Organization, vol. 22, no 6, pp. 826-842. 